\title{
THE USE OF OPERANT CONDITIONING TECHNIQUES IN THE RESPIRATORY REHABILITATION OF THE TETRAPLEGIC
}

\author{
By D. J. E. Cheshire, M.B.B.S.(Lond), D.Phys.Med.(Eng), D.P.R.M.(Aust) and \\ W. J. FLACK, R.T. \\ Southwest Regional Spinal Injuries Center and the Department of Respiratory Therapy, \\ Good Samaritan Hospital, Phoenix, Arizona, U.S.A.
}

\begin{abstract}
This paper discusses the development of a pilot project in respiratory rehabilitation as part of the total rehabilitation of the tetraplegic and high paraplegic. The principles of neuromuscular exercise and of behaviouristic psychology introduce the subject of operant learning in the rehabilitation setting. Incentive spirometry is described as the basic element in the development of a respiratory rehabilitation programme. The preliminary results are analysed and a recommendation made that such a programme materially increases the respiratory function of the tetraplegic, and, not least, assists in his ability to combat intercurrent respiratory infection.
\end{abstract}

Key words: Respiratory rehabilitation; Behaviouristic psychology; Incentive spirometry; Tetraplegia.

\section{Introduction}

MUCH experimental work has been done on the disordered respiratory physiology of the tetraplegic patient, and, as the whole field has broadened and become more sophisticated, so has our knowledge of tetraplegic patho-physiology (Gilliat et al., I948; Cameron et al., 1955; Wingo, 1957; McCredie et al., I962; Stone et al., I962, I963; Bergofsky, I964; Guttmann et al., I965; McKinley et al., I969; Silver et al., I969; Fugl-Meyer, I97I $a$; Fugl-Meyer et al., I971 $a$, $b$; Silver, I97I; Kokkola et al., I975; Ohry et al., I975). This is certainly true in academic physiology, and also in the management of respiratory failure and acute respiratory illness. Much less, however, is heard about the application of this knowledge to the rehabilitation process.

\section{Respiratory Rehabilitation}

Respiratory rehabilitation is a phrase which is rarely used in the tetraplegic context and a search of the literature identifies only one paper (Fugl-Meyer, I97Ib) which specifically considers a process of planned treatment which is directed at the achievement of maximum respiratory function in the tetraplegic patient.

All spinal cord injury physicians and therapists practise a rehabilitation regime which is aimed at strengthening the muscles of the shoulder girdle in order that the patient may learn to lift his body weight and safely to transfer it from his bed to his wheelchair. In doing this sequential rehabilitation task the fundamentals of athletic training are used. It is recognised that it is possible to isolate muscles and that, by volitional effort, repeated contractions of those muscles will become more efficient, particularly if a schedule is devised which utilises the principle of multiple repetitions and increasing load. From the viewpoint of respiratory rehabilitation it would appear that, from all the physiological work, two funda- 
mental facts emerge. The first of these is that the vital capacity is diminished, hence also the ability to inspire deeply for vigorous expiration and the expectoration of secretions. The second fact is that stiffness of the rib cage may develop due to a decreased range of motion of the rib joints and a hyperactive stretch reflex activity in the paralysed intercostal muscles (Fugl-Meyer \& Grimby, 197I $b$ ).

The purpose of this paper is to suggest that a planned programme of respiratory rehabilitation is of integral importance in the overall treatment of the patient and that such a respiratory programme can be devised, utilising the latest physiological and psychological knowledge and with new equipment which is just becoming available.

The respiratory function of the tetraplegic is rarely a problem when the patient is well, because a vital capacity of $2000 \mathrm{ml}$ is adequate for the majority of the tasks of the physically limited tetraplegic, but it is a matter of great overall concern because we are now in a period of history when the greatest single cause of both death and long-term morbidity in the complete tetraplegic is respiratory infection (Silver et al., I968). It is in the context of the ability of the patient to handle a respiratory infection that the vital capacity becomes of critical importance. In the patient with respiratory infection, the greater the vital capacity, the greater the ability to move secretions from the alveoli into the airways, hence minimising the chances of consolidation and the complications of inadequate gas exchange in the alveoli. The majority of complete tetraplegics are unable to bring sputum to the mouth. If they have an adequate vital capacity, they are able to bring sputum from the alveoli to the airways, but they require assisted coughing to bring the sputum from the airways to the mouth. It is merely to state the obvious that the efficiency of assisted coughing is directly proportional to the patient's vital capacity. The more air that he can draw in, the greater is the volume of air and the force with which the air can, by assisted coughing, be used to propel the sputum from the airways to the mouth for expectoration.

One of the problems in the rehabilitation of the tetraplegic patient is that, particularly with high lesions, it is difficult to provide immediate obvious successes. The patient has had an overwhelming physical and psychological injury and the future appears to have nothing but gloom and dependency to offer. To break through this barrier of defeat, the patient often has an urgent need for something which will give him an early, obvious, visible or tangible success.

\section{Incentive Spirometry}

Incentive spirometry is not a particularly new concept, but there are, to date, only two papers in the literature (Van Der Water et al., I972; Bartlett et al., I973), and both of these are concerned with the prevention of postoperative pulmonary complications in able-bodied patients. The first incentive spirometers were peculiarly lacking in incentive or challenge and it was not until the marketing of the Spirocare machine, or, to give it its full title, 'The Spirocare Incentive Breathing Exerciser', that it was possible to develop a realistic programme which fitted the physical and psychological needs of the tetraplegic patient. ${ }^{1}$ To the best of our knowledge, it was in Phoenix that the 'Spirocare' incentive spirometer was first seen to have another function, that of respiratory rehabilitation of the patient with intercostal paralysis and an inadequately trained and inadequately utilised diaphragm (Fig. I).

${ }^{1}$ The Spirocare Incentive Breathing Exerciser was developed and is marketed by Marion Laboratories, Inc., Kansas City, Missouri 64137, U.S.A. 


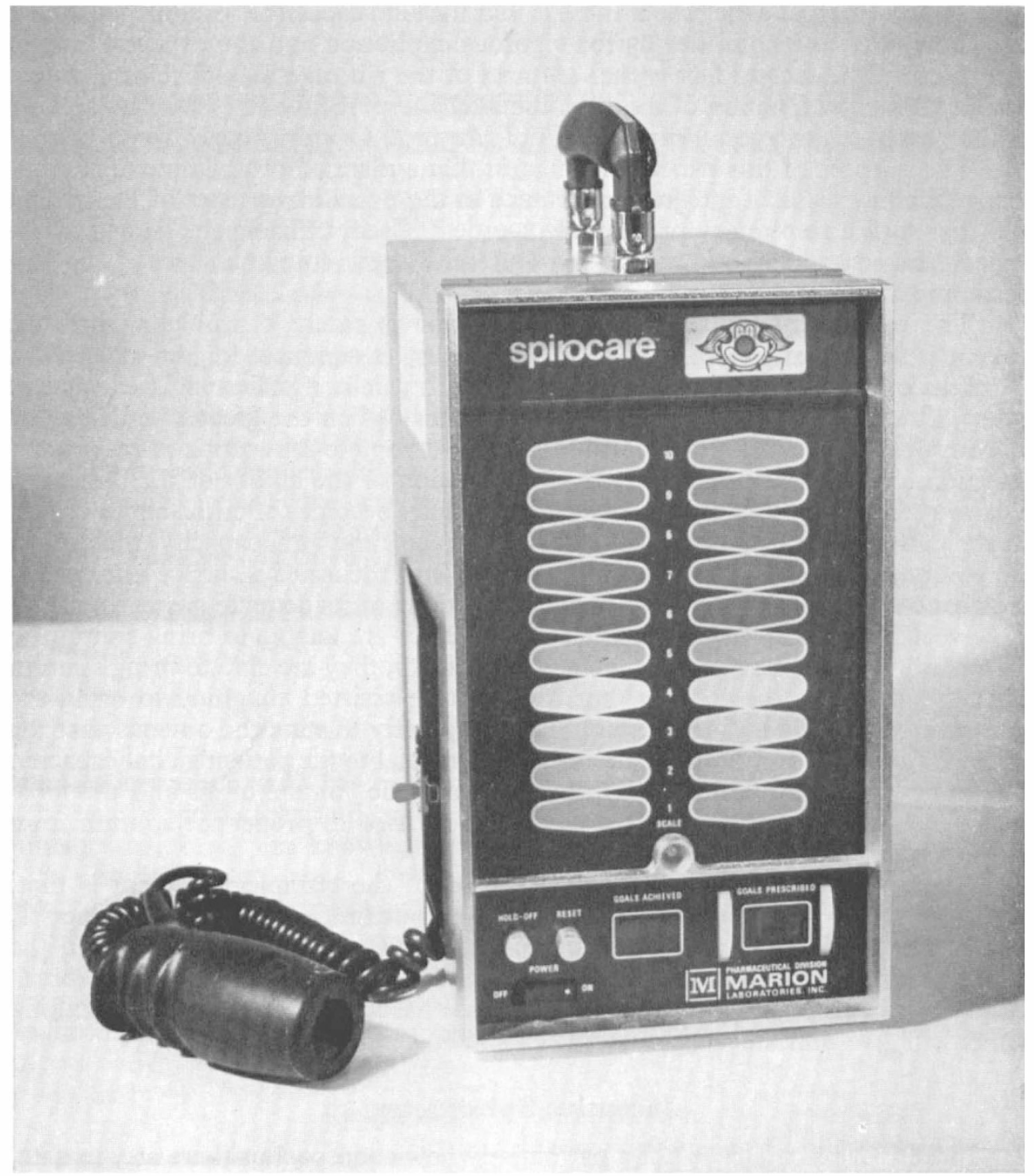

FIG. I

The spirometer is described as 'colorfully designed to encourage the patient's cooperation whilst he improves his breathing capacity. Colored lights signal the achievement of sustained maximum inspiration goals.' A therapist shows the spirometer to the patient and demonstrates the three separate volume light scales, numbered from one to ten, reading from the bottom to the top, on the front panel. From his knowledge of the patient's vital capacity, the therapist selects the appropriate scale, the first running from $250 \mathrm{ml}$ to $1375 \mathrm{ml}$, with volume increments of I $25 \mathrm{ml}$, the second from $500 \mathrm{ml}$ to $2750 \mathrm{ml}$, with volume increments of $250 \mathrm{ml}$, and the third from 1000 to $5500 \mathrm{ml}$, with volume increments of $500 \mathrm{ml}$. If the target or challenge is set by the therapist in the right-hand column, the patient, as 
he inspires, will see a succession of coloured lights running up the left-hand column, and if he manages by the force of his inspiration to match on the left-hand column the target on the right-hand column, the clown's face at the top lights up.

\section{Operant Conditioning}

To a greater or lesser degree, and with variable degrees of awareness, most people practising rehabilitation medicine today are leaning very heavily upon Skinner's work (1972, 1974) and his elucidation of the principles of behaviouristic psychology. The behavioural approach is based on the principles of operant learning and there is now an abundant accumulated literature (Trombly, I966; Fordyce, I968; Michael, I970; Fordyce et al., I971; Sand et al., I973; Fordyce et al., I973) which proves that operant learning principles are highly effective in the field of rehabilitation medicine. In the present specific context the behaviour pattern of the newly tetraplegic patient may be termed an operant. Operant conditioning refers to the functional principles by which behaviour may be modified. Operants are, in general, capable of being elicited by antecedent stimuli and, certainly true in the tetraplegic, are also subject to influence by consequences. When an operant is followed by positive consequences, for example a re-enforcer such as praise and attention from either the treating staff or other patients, that behaviour is more likely to occur in the future. The behaviour will be strengthened or increased in rate of occurrence. When an operant is followed by a negative consequence, for example criticism or negative reactions of staff and peers, that behaviour is likely to occur less frequently in the future and behaviour designed to remove negative consequences or avoid it is likely to increase.

\section{The Rehabilitation Programme}

To return to the direct context of the newly tetraplegic patient and his severely impaired ventilation, if one is able only to present a nebulous and often meaningless programme it is extremely difficult for the patient to develop any enthusiasm or desire to participate in an ongoing programme of multiple repetitions. This is where the 'Spirocare' incentive Spirometer has such very great advantages. The patient is able to see a target and an illuminated coloured light on the right-hand scale is to the average person a much more meaningful target than a volumetric number. If, with the spirometer, the target consists of an illuminated light half way up a scale and, when he inspires, he is able to watch a succession of coloured lights running up the left-hand column to match the target set in the right-hand column, this is much more meaningful than trying to achieve some incomprehensible numerical result (Fig. 2).

Here, as in practically every aspect of rehabilitation medicine, one comes to the crucial factor which so often makes the difference between success and failure, namely the personality and the enthusiasm of the therapist. It is absolutely futile to give the patient an incentive spirometer, instruct him in its use and then leave him alone. The therapist must remain with the patient and must convey, by his own attitudes and reactions, an enthusiasm which becomes infectious to the patient. This programme has proved to be so successful that patients are setting something of a strain on the staff in their demands to go beyond two treatments a day to three or four or five. A patient who is demanding five 20-min treatments a 


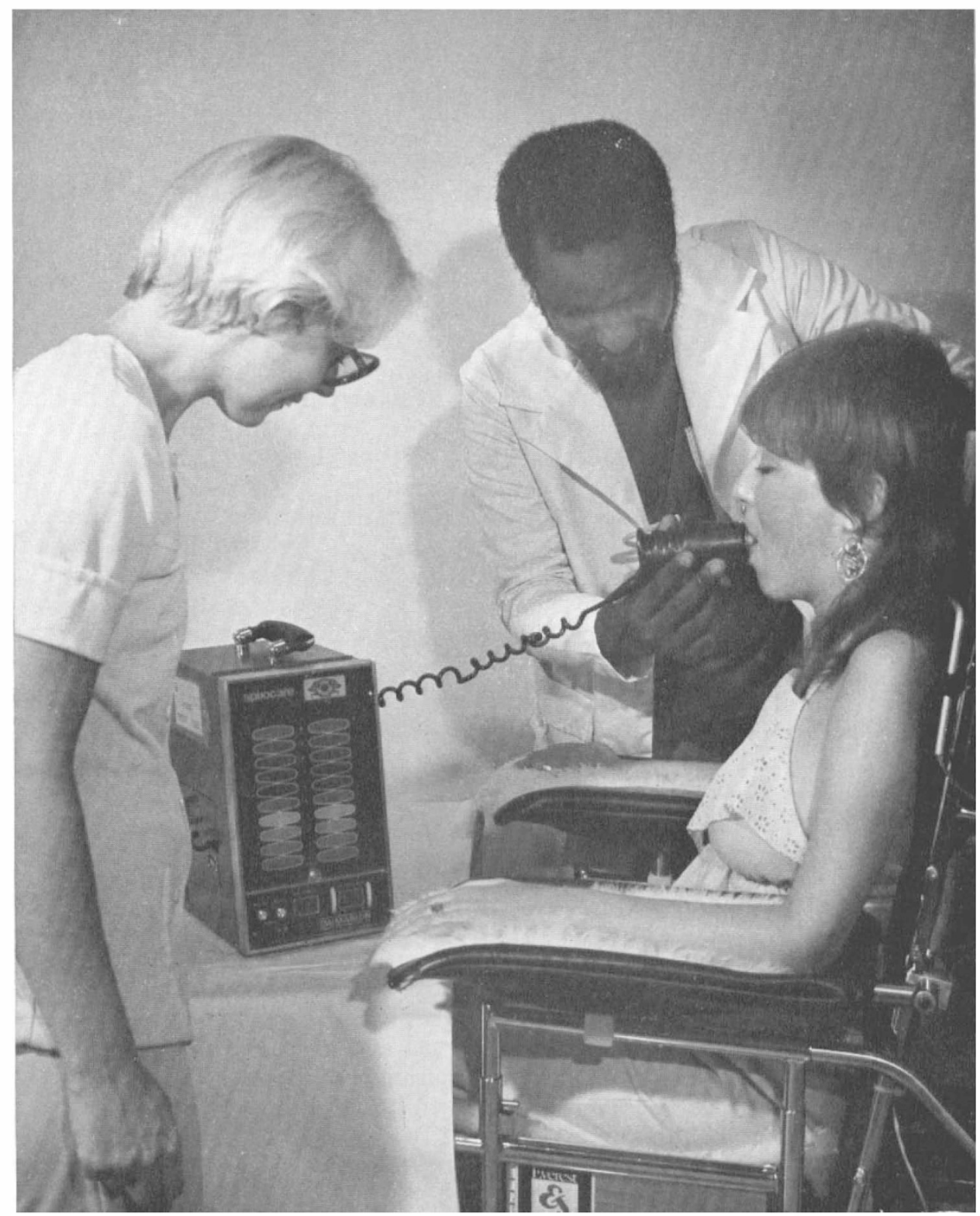

FIG. 2

day is indeed applying the fundamental principles of muscle re-education and work hypertrophy to the diaphragm. At the same time as he achieves his target, he is achieving sucess and his success is positively re-enforced by the reaction of his therapist and his peers. Peer competition and challenge are frequent and, of some interest, the spirometer has proved equally challenging to patients of all 
levels of intelligence and sophistication. The programme has so far included patients from I 4 to 89 years of age, and from total illiteracy to Masters of Arts.

It is now that we find the realisation of a programme designed to help a patient to achieve a maximum vital capacity in order the better to cope with future respiratory illness and also one which uses the psychological mechanism of positive re-enforcement in the process of operant conditioning. Thereby, through early success, the patient is given more incentive to tackle the physically and psychologically arduous demands of the whole rehabilitation programme. In order to achieve the most successful results, it is felt that the patient should be introduced to the respiratory rehabilitation programme as early as possible. For example, if one is weaning a patient from a ventilator, a vital capacity of $500 \mathrm{ml}$ is certainly not too soon to start the programme. This is the patient who is the most likely to be profoundly depressed, with reason, and $500 \mathrm{ml}$ is an achieveable target on the 'Spirocare' spirometer.

\section{Results}

In attempting to assess the results which have to date been achieved with this respiratory rehabilitation programme using incentive spirometry, it is easy to state that the patients so treated have shown definite improvement in their psychological approach to the total rehabilitation task. It is felt that this programme of respiratory rehabilitation has been successful in giving the patients clearly visible success at an early statge in their rehabilitation and that the continuation of this respiratory programme has maintained impetus with results that have been obvious not only in the direct field of respiratory rehabilitation, but have also flowed over into all aspects of physical and psychological rehabilitation. It is felt that this particular programme gives support to previously expressed opinions that the behaviouristic psychological approach based on operant learning principles has a very large part to play in the total structure of the rehabilitation environment of the tetraplegic patient.

In terms of respiratory rehabilitation, it is much easier to have strong clinical impressions than it is to have direct numerical comparisons. In a previous paper by one of us (Cheshire et al., I966) the respiratory function of an experimental group of ten tetraplegic patients was investigated. All these patients were male, all had complete lesions of the cervical spinal cord below $\mathrm{C}_{5}$ or $\mathrm{C} 6$, all had complete absence of any pre-accident history of respiratory disease and all were in a state of respiratory stability. The patients' ages were between I 4 and 46 years and their time from injury ranged between 3 and IIO months. In these ten randomly selected male tetraplegics, the lowest vital capacity was I I00 $\mathrm{ml}$ and the highest was $3000 \mathrm{ml}$, an average of $1870 \mathrm{ml}$. We regret that we are now unable to relate these vital capacities to the theoretical normal values, but it seems to us, in the light of our recent work, that these patients had extremely low respiratory function (Table I).

A problem of significant magnitude in the interpretation and assessment of this work is the difficulty in defining the normal or the predictable pulmonary function of the tetraplegic. The more one studies the literature the more confused one becomes. The basis respiratory references neither agree with one another, nor with the neurological or physiological references (Table II). One can find assertions that 70 per cent of respiratory function derives from intercostal muscle function and others state that diaphragmatic, abdominal and accessory muscle function can account for up to 70 per cent of respiratory function. Clearly both cannot be correct. Without independent research work upon which to rely an

I6/2-M 


\section{TABLE I}

Tidal volumes and vital capacities in stabilised tetraplegics

(after Cheshire et al., I966)

\begin{tabular}{cccccc}
\hline Subject & $\begin{array}{c}\text { Age } \\
\text { (yrs) }\end{array}$ & $\begin{array}{c}\text { Cervical cord } \\
\text { lesion }\end{array}$ & $\begin{array}{c}\text { Time } \\
\text { since } \\
\text { accident } \\
\text { (months) }\end{array}$ & $\begin{array}{c}\text { Tidal } \\
\text { volume } \\
\text { (ml) }\end{array}$ & $\begin{array}{c}\text { Vital } \\
\text { capacity } \\
\text { (ml) }\end{array}$ \\
\hline I G. B. & 2I & Complete below C6 & 3 & 310 & 2200 \\
2 B. R. & 27 & Complete below C6 & 3 & 460 & 2000 \\
3 D. C. & I4 & Complete below C6 & 4 & 445 & 2000 \\
4 A. M. & I9 & Complete below C5 & 23 & 500 & 1950 \\
5 B. P. & 28 & Complete below C5 & 33 & 530 & 3000 \\
6 B. S. & 29 & Complete below C5 & 38 & 250 & I500 \\
7 A. P. & 45 & Complete below C6 & 39 & 470 & 1550 \\
8 K. R. & 23 & Complete below C6 & 42 & 265 & 2200 \\
9 S. E. & 38 & Complete below C6 & 64 & 500 & I I00 \\
I0 G. S. & 28 & Complete below C6 & I IO & 220 & I200 \\
\hline
\end{tabular}

TABLE II

Respiratory mechanics-percentile division between intercostal and diaphragmatic components

\begin{tabular}{lc}
\hline \multicolumn{1}{c}{ Author } & $\begin{array}{c}\text { Percentage } \\
\text { attributed } \\
\text { to diaphragm }\end{array}$ \\
\hline Campbell, I958 & $60 \%$ \\
Crofton, I969 & 75 \\
Conroe, I97I & 50 \\
Collins, I966 & 50 \\
Egan, I973 & 75 \\
Burke \& Murray, I975 & 40 \\
Cotes, I975 & 70 \\
Wang, I972 & 60 \\
Grimby, I968 & 30 \\
\hline
\end{tabular}

attempt has been made to strike a balance between conflicting views, and much weight has been given to the concurring opinion in three major papers (Cameron et al., 1955; Hemingway et al., 1958; Bergofsky, 1964) that two-thirds of the vital capacity is generated from diaphragmatic and accessory muscle function and onethird from intercostal muscle function.

The results reported are based upon two assumptions: (I) That the theoretical maximum vital capacity of the complete tetraplegic is 70 per cent of the neurologically intact individual of the same sex, age and height, and (2) that meaningful 
analysis of the results of the programme requires study of both absolute values of vital capacity before and after the course of treatment and the expression of the achieved vital capacity as a percentage of the theoretical tetraplegic maximum, as defined above.

In the series being reported only patients with complete tetraplegia are included, and all were free of any pre-injury respiratory disease. All the vital capacities recorded at the end of the programme of incentive spirometry were taken with the patient seated erect in a wheelchair and wearing an elastic abdominal binder. The theoretical vital capacities are taken from the nomogram devised by Kory et al. (I96I).

The patients studied fall into three groups. Group I: Patients with new lesions whose course of treatment started as part of the process of weaning from a ventilator (Table III); Group II: Patients with new lesions who did not require ventilatory assistance (Table IV); and Group III: Patients with old, stabilised spinal cord injuries who were readmitted to hospital for the treatment of acute respiratory illness (Table V).

It is felt that insufficient patients have yet been fully studied to permit more than generalised conclusions. It is, however, the authors' impression that higher vital capacities are being achieved than were previously being reached by comparable patients. The two female patients in Group III are of interest in that these women, with stabilised cord lesions, were able to add, respectively, ro50 $\mathrm{ml}$ and $875 \mathrm{ml}$ to their previous maximum vital capacities. Both patients have subsequently reported a greatly improved ability to cope with the day-to-day respiratory problem of clearing sputum.

It is no surprise that the patient with the lowest ending vital capacity, expressed as a percentage of the predicted vital capacity, was a patient who remains with a diaphragmatic hemiparesis, but, notwithstanding, $2000 \mathrm{ml}$ represented a creditable achievement for a boy who was admitted to the Centre having been told that he would need lifelong ventilatory support.

It is also felt to be of interest, and a field for future study, that, using a nomogram of Kory et al. (196I), the predicted tetraplegic vital capacity was achieved with apparently greater facility and frequency by females than by males. This finding is not adequately explained, but may be related to a fundamental error in the construction of the nomogram. It is also abundantly obvious that accurate work with tetraplegics can no longer depend on a 'best-guess' of the relationship between the predicted normal FVC in the able-bodied subject and an attempt to ascribe a 'normal' value to the tetraplegic. Any such assumption is based on the potential double error of uncertainty of 'normal' values in the able-bodied and, also, the uncertainty of the percentile relationship between the able-bodied and the tetraplegic.

A collaborative inter-centre research project to collect data on a large number of complete tetraplegics and thence to construct a tetraplegic nomogram would appear overdue, but is now possible using the facilities of the United States National Spinal Cord Injury Data Research Center.

The authors are confident that a programme of incentive spirometry has great value in the respiratory rehabilitation of the tetraplegic and that such a programme spreads major benefits into the whole scheme of rehabilitation with major gains in both the psychological and the physical components. We are also convinced that the patient whose treatment is conducted by a respiratory therapist with the active re-enforcement of a nurse or physical therapist does better than the patient who works alone with a respiratory therapist. 
TABLE III

Group I: All patients requiring ventilator assistance when treatment started. All new lesions

\begin{tabular}{|c|c|c|c|c|c|c|c|c|c|c|}
\hline $\begin{array}{l}\text { Patient } \\
\text { number }\end{array}$ & $\begin{array}{l}\text { Cervical cord } \\
\text { lesion complete } \\
\text { below }\end{array}$ & Sex & Age & Height & $\begin{array}{l}\text { Time from } \\
\text { injury to start } \\
\text { of spirometry } \\
\text { programme }\end{array}$ & $\begin{array}{l}\text { Duration } \\
\text { of } \\
\text { treatment }\end{array}$ & $\begin{array}{l}\text { Starting } \\
\text { FVC } \\
\text { (ml) }\end{array}$ & $\begin{array}{l}\text { Ending } \\
\text { FVC } \\
\text { (ml) }\end{array}$ & $\begin{array}{l}\text { Predicted } \\
\text { FVC } \\
\text { (ml) }\end{array}$ & $\begin{array}{c}\% \text { age } \\
\text { of } \\
\text { predicted }\end{array}$ \\
\hline I & $\mathrm{C}_{4}$ & $\mathrm{~F}$ & 25 & $\begin{array}{c}62 \text { in } \\
157 \mathrm{~cm}\end{array}$ & 7 wks & I 2 wks & 500 & 2400 & 2275 & $105 \%$ \\
\hline 2 & $\mathrm{C}_{4}$ & M & I6 & $\begin{array}{l}72 \text { in } \\
183 \mathrm{~cm}\end{array}$ & 8 wks & 9 wks & 200 & 2000 & 2905 & $70 *$ \\
\hline 3 & $\mathrm{C}_{4}$ & $\mathrm{~F}$ & 29 & $\begin{array}{c}6 \mathrm{I} \text { in } \\
155 \mathrm{~cm}\end{array}$ & 9 wks & $6 \mathrm{wks}$ & 300 & 1950 & 2205 & 89 \\
\hline 4 & $\mathrm{C}_{4}$ & $\mathrm{~F}$ & 28 & $\begin{array}{c}66 \mathrm{in} \\
168 \mathrm{~cm}\end{array}$ & 6 wks & $5 \mathrm{wks}$ & 150 & 2725 & 2604 & 107 \\
\hline 5 & $\mathrm{C}_{4}$ & $M$ & 25 & $\begin{array}{c}70 \text { in } \\
178 \mathrm{~cm}\end{array}$ & $3 \mathrm{wks}$ & I 4 wks & 700 & 3250 & 3090 & 105 \\
\hline
\end{tabular}

* Patient has diaphragmatic hemiparesis. 
TABLE IV

Group II: All new lesions. No assisted ventilation needed

\begin{tabular}{|c|c|c|c|c|c|c|c|c|c|c|}
\hline $\begin{array}{l}\text { Patient } \\
\text { number }\end{array}$ & $\begin{array}{l}\text { Cervical cord } \\
\text { lesion complete } \\
\text { below }\end{array}$ & Sex & Age & Height & $\begin{array}{l}\text { Time from } \\
\text { injury to start } \\
\text { of spirometry } \\
\text { programme }\end{array}$ & $\begin{array}{l}\text { Duration } \\
\text { of } \\
\text { treatment }\end{array}$ & $\begin{array}{l}\text { Starting } \\
\text { FVC } \\
(\mathrm{ml})\end{array}$ & $\begin{array}{l}\text { Ending } \\
\text { FVC } \\
(\mathrm{ml})\end{array}$ & $\begin{array}{l}\text { Predicted } \\
\text { FVC } \\
\text { (ml) }\end{array}$ & $\begin{array}{l}\% \text { age } \\
\text { of } \\
\text { predicted }\end{array}$ \\
\hline I & C6 & F & I4 & \multirow{5}{*}{$\begin{array}{c}59 \mathrm{in} \\
150 \mathrm{~cm} \\
64 \mathrm{in} \\
163 \mathrm{~cm} \\
68 \mathrm{in} \\
173 \mathrm{~cm} \\
68 \mathrm{in} \\
173 \mathrm{~cm} \\
74 \mathrm{in} \\
188 \mathrm{~cm}\end{array}$} & $3 \mathrm{wks}$ & 9 wks & 900 & 2250 & 2223 & IOI \% \\
\hline 2 & $\mathrm{C}_{5}$ & $\mathbf{M}$ & 27 & & 2 wks & I I wks & I 450 & 3250 & 3010 & 107 \\
\hline 3 & $\mathrm{C}_{4}$ & $M$ & I 8 & & I2 wks & $7 \mathrm{wks}$ & 1600 & 2750 & 3517 & 78 \\
\hline 4 & $\mathrm{C}_{5}$ & $\mathbf{M}$ & 26 & & I wk & $4 \mathrm{wks}$ & 2300 & 3250 & 3395 & 96 \\
\hline 5 & C6 & $M$ & 23 & & $3 \mathrm{wks}$ & I4 wks & I900 & 3500 & 4025 & 86 \\
\hline \multicolumn{11}{|c|}{ Group III: Old lesions. } \\
\hline $\begin{array}{l}\text { Patient } \\
\text { number }\end{array}$ & $\begin{array}{l}\text { Cervical cord } \\
\text { lesion complete } \\
\text { below }\end{array}$ & Sex & Age & Height & $\begin{array}{l}\text { Time from } \\
\text { injury to start } \\
\text { of spirometry } \\
\text { programme }\end{array}$ & $\begin{array}{l}\text { Duration } \\
\text { of } \\
\text { treatment }\end{array}$ & $\begin{array}{l}\text { Starting } \\
\text { FVC } \\
(\mathrm{ml})\end{array}$ & $\begin{array}{l}\text { Ending } \\
\text { FVC } \\
(\mathrm{ml})\end{array}$ & $\begin{array}{l}\text { Predicted } \\
\text { FVC } \\
\text { (ml) }\end{array}$ & $\begin{array}{l}\% \text { age } \\
\text { of } \\
\text { predicted }\end{array}$ \\
\hline I & $\mathrm{C}_{5}$ & $\mathrm{~F}$ & $4 \mathrm{I}$ & $\begin{array}{c}61 \text { in } \\
155 \mathrm{~cm}\end{array}$ & II3 wks & 6 wks & I 200 & 2250 & 2065 & $109 \%$ \\
\hline 2 & C6 & $\mathrm{F}$ & 24 & $\begin{array}{l}58 \mathrm{in} \\
147 \mathrm{~cm}\end{array}$ & 208 wks & $6 \mathrm{wks}$ & 1400 & 2275 & I976 & II 5 \\
\hline
\end{tabular}




\section{SUMMARY}

A formal programme of respiratory rehabilitation has been lacking in the total rehabilitation of tetraplegic and high paraplegic patients. Such a pilot programme has been completed, based on the fundamental principles of neuromuscular exercise and behaviouristic psychology. The programme utilises incentive spirometry, specifically the "Spirocare Incentive Breathing Exerciser" as its central feature. Criteria for the analysis of results have been established and, utilising these criteria, the preliminary results suggest that a materially significant increase in the respiratory function of the tetraplegic patient can be achieved. These results are related to the practical need to assist the patient to combat intercurrent respiratory infection.

Acknowledgements. The authors wish to express their sincere thanks to the patients, respiratory therapists, nurses and physical therapists who participated so enthusiastically in this pilot project. They are also indebted to Marion Laboratories, Inc., and especially Mr Jean Sperry, President, International Division, and Dr Robert Henderson, Medical Director, for their encouragement and invaluable support.

They wish also to thank Ms Donna Rae Cintora, Medical Librarian, National Spinal Cord Injury Data Research Center, for assistance with the bibliography and Ms Jeanne Stahl for typing the manuscript.

\section{REFERENCES}

Barlett, R. H., Gazzaniga, A. B. \& Geraghty, T. R. (I973). Respiratory maneuvers to prevent post-operative pulmonary complications. f. Amer. Med. Assoc., 224, IOI7IO2I.

BERGOFSKY, E. H. (1964). Quantitation of the function of respiratory muscles in normal individuals and quadraplegic patients. Arch. Phys. Med., 45, 575-580.

Burke, D. C. \& Murray, D. D. (1975). Handbook of Spinal Cord Medicine, p. 32. Macmillan Press Ltd., London.

Cameron, G. S., Scott, J. W., Jousse, A. T. \& Botterell, E. H. (1955). Diaphragmatic respiration in a quadriplegic patient and effect of position on his vital capacity. Ann. Surg., I4I, 45I-456.

CAMPBell, E. J. M. (1958). The Diaphragm, the Respiratory Muscles and the Mechanics of Breathing, pp. 8-16. Lloyd-Luke, London.

Cheshire, D. J. E. \& CoATs, D. A. (1966). Respiratory and metabolic management in tetraplegia. Paraplegia, 4, I-23.

Collins, V. J. (196I). Principles of Anesthesiology, p. 827. Lea \& Febinger, Philadephia.

Conroe, J. H., Jr. (I97I). Physiology of Respiration, p. 99. Year Book Medical Publishers, Inc., Chicago.

Cotes, J. E. (1975). Lung Function, 3rd edn., p. 67. Blackwell Scientific Publications, Oxford.

Crofton, J. \& Douglas, A. (1975). Respiratory Diseases, 2nd edn., p. 679. Blackwell Scientific Publications, Oxford.

Egan, D. F. (1973). Fundamentals of Respiratory Therapy, and edn., p. 65. The C. V. Mosby Co., St Louis.

FordyCE, W. E. (1968). Psychology and Rehabilitation: Rehabilitation and Medicine, pp. I29-I5I. E. Licht, New Haven.

Fordyce, W. E., Fowler, R. S., Lehmann, J. F., Delabeur, B. J., Sand, P. L. \& Trieschmann, R. B. (1973). Operant conditioning in the treatment of chronic pain. Arch. Phys. Med. Rehab., 54, 399-408. 
Fordyce, W. E., SAND, P. L., Trieschman, R. B. et al. (I97I). Behavioural systems analyzed. F. Rehab., 33, 29-33.

Fugl-MeYeR, A. R. (I97I $a$ ). Effects of respiratory muscle paralysis in tetrgic andaple paraplegic patients. Scand. F. Rehab. Med., 3, I4I-I5O.

FUgL-MEYeR, A. R. (I97I $b$ ). A model for treatment of impaired ventilatory function in tetraplegic patients. Scand. F. Rehab. Med., 3, I68-I77.

Fugl-Meyer, A. R. \& Grimby, G. (I97I $a$ ). Ventilatory function in tetraplegic patients. Scand. F. Rehab. Med., 3, I5I-160.

Fugl-Meyer, A. R. \& Grimby, G. (I97I $b$ ). Rib cage and abdominal volume ventilation partitioning in tetraplegic patients. Scand. F. Rehab. Med., 3, I6I-I67.

Gilliat, R. W., GuttmanN, L. \& Whitteridge, D. (I948). Inspiratory vasoconstriction after spinal injuries. F. Physiol., 1071, 67.

Grimby, G., BunN, J. \& MEAD, J. (I968). Relative contributions of the rib cage and abdomen to ventilation during exercise. F. Appl. Physiol., 24, I59-166.

Guttmann, L. (1976). Spinal Cord Injuries. Comprehensive Management and Research, 2nd Edition. Blackwell Scientific Publications, Oxford.

GutTMANN, L. \& Silver, J. R. (I965). Electromyographic studies on reflex activity of the intercostals and abdominals in cervical cord injuries. Paraplegia, 3, I-22.

Hemingway, A., Bors, E. \& Hobby, R. P. (1958). An investigation of the pulmonary function of paraplegics. F. Clin. Invest., 37, 773-782.

Kokkola, K., Moller, K. \& Lehtonen, T. (1975). Pulmonary function in tetraplegic and paraplegic patients. Ann. Clin. Res., 7, 76-79.

Kory, R. C., Callahan, R., Boren, H. G. \& Syner, J. C. (I96I). Clinical spirometry in normal men. Amer. F. Med., 30, 243-258.

McCredie, J. Lovejoy, F. W., JR. \& Kaetreider, N. L. (I962). Pulmonary function in diaphragmatic paralysis. Thorax, 17, 213.

McKinley, A. C., Auchinloss, J. H., Jr., Gilbert, R. \& Nicholas, J. J. (I969). Pulmonary function, ventilatory control and respiratory complications in quadriplegic subjects. Amer. Rev. Respir. Dis., 100, 526-532.

MiChaEL, J. L. (I970). Rehabilitation in C. Neuring and J. L. Michael, (eds.), Behaviour Modification in Clinical Psychology, pp. 52-85. Appleton-Century-Crofts, New York.

Ohry, A., Molmo, M. \& Rozin, R. (1975). Alterations of pulmonary function in spinal cord injured patients. Paraplegia, I3, IOI-IO8.

SAND, P. L., FordyCE, W. E. \& FowleR, R. S. (1973). Fluid intake behaviour in patients with spinal cord injury: prediction and modification. Arch. Phys. Med. Rehab., 54, 254-262.

Silver, J. R. \& Gibbon, N. O. K. (I968). Prognosis in tetraplegia. Brit. Med. f., 4, 79-83.

Silver, J. R. \& ABDEL-Halim, R. E. (I97I). Chest movements and electromyography of the intercostal muscles in tetraplegic patients. Paraplegia, 9, I23-I3I.

Silver, J. R. \& Moulton, A. (I969). The physiological and pathological sequelae of paralysis of the intercostal and abdominal muscles in tetraplegic patients. Paraplegia, 7, I3I-I4I.

Skinner, B. F. (1972). Cumulative Record: A Selection of Papers, 3rd edition. AppletonCentury-Crofts, New York.

Skinner, B. F. (1974). About Behaviourism, pp. 39-40, 47-73. Alfred A. Knopf, Inc., New York.

STONE, D. J. (1962). Some aspects of lung function in patients with respiratory muscle paralysis due to spinal cord injury. Proc. I Ith Ann. Clin. Spinal Cord Injury Conf., II, I 53-I 56.

Stone, D. J. \& Keltz, H. (1963). The effect of respiratory muscle dysfunction on pulmonary function. Studies in patients with spinal cord injuries. Amer. Rev. Respir. Dis., 88, 62 I-629.

Trombly, C. A. (1966). Principles of operant conditioning: related to orthotic training of quardiplegic patients. Amer. F. Occup. Ther., 21, 217-220. 
Van Der Water, J. M., Waring, W. G., Linton, L. A., Murphy, M., Byron, R. L. (1972). Prevention of post-operative pulmonary complications. Surg. Gynecol. Obstet., 135, 229-233.

Wang, C. S., Josenhau, W. T. (1972). Year Book of Anesthesia, p. 280. Year Book Publishers, Inc., Chicago.

WiNgo, C. F. (1957). Pulmonary ventilation studies in a group of twenty quadriplegic patients. Roc. 6th Ann. Clinc. Spinal Cord Injury Conf., 6, 23-32. 